\title{
Influences of hydrocarbons on porosity enhancement in deep Ediacaran dolomite reservoirs
}

DONGYA ZHU, QUANYOU LIU, ZHILIANG HE

Petroleum Exploration and Production Research Institute of SINOPEC, No. 31 Xueyuan Road, Beijing, 100083;

zhudy.syky@sinopec.com

The ancient Ediacaran Dengying Formation $\left(\mathrm{Z}_{2} \mathrm{dn}\right)$ dolomite reservoirs, in the Sichuan Basin, southern China currently have a high porosity $(\sim 15 \%)$ even after a long and complicate diagenetic evolution. However, a clear model for the development and preservation of the porosity has yet to be determined. This paper presents geological and geochemical evidence to reveal the enhancing influences of hydrocarbons on development and preservation of porosity.

First, the experiment of carbonate dissolution by hydrocarbon-bearing fluids was carried out. The results showed that the hydrocarbon-bearing acidic fluids originated from hydrocarbon source rocks could significantly dissolved carbonates. In the $\mathrm{Z}_{2} \mathrm{dn}$ dolomites, evidence can be observed that the hydrocarbon-bearing fluids migrated along fractures as well as stylolites into the dolomites and heavily dissolved the surrounding rocks. The altered dolomites around dissolution pores have a light carbon isotope composition $\left(\delta^{13} \mathrm{CVPDB}_{\mathrm{VP}},-17.3 \%\right.$ ), indicating the organic dissolution.

Second, the presence of petroleum allowed the existing pore spaces to be maintained for a long geological time. Since the Triassic, the petroleum in the $\mathrm{Z}_{2} \mathrm{dn}$ reservoirs was thermally cracked into gases and pyrobitumen; both petroleum and pyrobitumen adhered to the pore surfaces to form a bitumen coating that hindered contact between the pore fluids and the carbonate rocks, thus inhibiting the precipitation of cement minerals and helping preserve the existing porosity. In contrast, the pore spaces in dolomites lacking pyrobitumen were continuously cemented by dolomite. The gradual increase in the homogenization temperatures $\left(\mathrm{T}_{\mathrm{h}}\right.$, from $53.5{ }^{\circ} \mathrm{C}$ to $238.7{ }^{\circ} \mathrm{C}$ ) of the fluid inclusions in dolomite cements as well as the gradual decrease in $\delta^{18}$ OvpDB values (from $-7.8 \%$ to $-11.4 \%$ ) of the dolomite cements suggested the continuous cementation with increasing burial depth.

Third, an acidic formation water due to presence of $\mathrm{H}_{2} \mathrm{~S}$ and $\mathrm{CO}_{2}$ not only inhibited precipitation of cement minerals but also enhanced porosity by dissolving carbonates. Since the Triassic, the levels of $\mathrm{H}_{2} \mathrm{~S}$ and $\mathrm{CO}_{2}$ continuously gained up and up $\left(\mathrm{H}_{2} \mathrm{~S}+\mathrm{CO}_{2}, \sim 15 \%\right)$ in the $\mathrm{Z}_{2} \mathrm{dn}$ reservoirs due to thermochemical sulfate reduction (TSR) process involving consumption of hydrocarbons. The porosity in the dolomites is positively correlated with the abundance of $\mathrm{H}_{2} \mathrm{~S}$ and $\mathrm{CO}_{2}$, suggesting the enhancing effect. 